\title{
Kepatuhan Masyarakat terhadap Protokol COVID-19 pada Masa Pemberlakuan New Normal di Kota Jayapura, Provinsi Papua, Indonesia
}

\author{
Bouway Dolfinus.Y. ${ }^{1}$, Sinaga Yoshua.I. ${ }^{2}$, Mamani Christanto.R. ${ }^{2}$, Subratha I Dewa.G.A. ${ }^{2}$, Azwad \\ Rizky.H. ${ }^{2}$, Ratnasariani.W. ${ }^{2}$, Aibesa Adventa.A.M. ${ }^{2}$ \\ ${ }^{1}$ Pusat Studi Bencana Universitas Cenderawasih \\ ${ }^{2}$ Bagian Epidemiologi Fakultas Kesehatan Masyarakat Universitas Cenderawasih
}

\author{
Info Artikel \\ Diterima 23 Februari 2021 \\ Disetujui 17 April 20212020 \\ Diterbitkan 30 April 2021
}

Kata Kunci:

Kepatuhan,

Protokol COVID-19,

New Normal

e-ISSN:

2613-9219

\section{Akreditasi Nasional: \\ Sinta 4}

\author{
Keywords: \\ Compliance, \\ COVID-19 Protocol, \\ New Normal \\ $\square^{\square}$ Coresponding author: \\ yuboepidfkm@gmail.com
}

\begin{abstract}
Abstrak
Latar belakang: Jumlah kasus COVID-19 di Kota Jayapura terus bertambah dengan peluang infeksi (Rt) 1,57. Hal ini menunjukkan bahwa COVID-19 di Kota Jayapura belum terkontrol. Kepatuhan masyarakat terhadap protokol kesehatan di kota ini masih rendah. Pemerintah daerah telah mengeluarkan peraturan daerah agar masyarakat mentaati protokol kesehatan. Penelitian ini bertujuan untuk mengetahui kepatuhan masyarakat pada protokol kesehatan saat pemberlakuan new normal di Kota Jayapura. Metode: Penelitian observasional kuantitatif dengan pendekatan cross-sectional analitik ini melibatkan 1.033 responden. Survey selama bulan Agustus 2020 ini mencakup 10 kelurahan dan 4 kampung di tiga kecamatan, yaitu Jayapura Utara, Abepura dan Heram. Pengumpulan data melalui wawancara berbasis kuesioner yang mencakup identitas responden, serta pengetahuan, sikap dan tindakan tentang protokol kesehatan. Data dianalisis secara univariat dan bivariat untuk menampilkan informasi besar risiko dan kemaknaan. Informasi kualitatif digunakan untuk mendukung penjelasan variabel penelitian. Hasil: Responden laki-laki lebih banyak $(51.7 \%)$ daripada perempuan (48.3\%). Karateristik suku terhadap tindakan penggunaan masker memiliki peluang 7 kali terinfeksi COVID-19 sedangkan karakteristik jenis kelamin, umur, pendidikan, pekerjaan dan agama terhadap tindakan penggunaan masker 2 kali terinfeksi. Kesimpulan: Pemberlakuan protokol kesehatan COVID-19 di Kota Jayapura belum dipatuhi dengan baik oleh masyarakat
\end{abstract}

\begin{abstract}
Background: The number of COVID-19 cases in Jayapura City continues to increase with the chance of infection (Rt) 1.57. This fact shows that COVID-19 in Jayapura City has not been controlled. People compliance with health protocols is still low. Local governments have issued local regulations so that people adhere to health protocols. This study aims to determine community compliance with health protocols during the implementation of the new normal in Jayapura City. Methods: This quantitative observational study with cross-sectional analytic approach involved 1,033 respondents. The survey was conducted during August 2020 covered 10 urban villages and 4 villages in three sub-districts, namely North Jayapura, Abepura and Heram. Data collection through questionnaire-based interviews which include the identity of the respondents, as well as knowledge, attitudes and actions about health protocols. Data were analyzed using univariate and bivariate methods to display information on risk and significance. Qualitative information is used to support the explanation of the research variables. Results: Male respondents $(51.7 \%)$ more than women (48.3\%). Ethnic have a seven times chance of being infected with COVID-19 while the characteristics of gender, age, education, occupation and religion of the act of using masks are twice infected. Conclusion: The people have not followed the implementation of the health protocol of COVID-19 in Jayapura City.
\end{abstract}

(C) 2021 Program Studi S-1 Kesehatan Masyarakat Universitas Muhammadiyah Semarang 


\section{Pendahuluan}

Studi epidemiologi dan virologi saat ini membuktikan bahwa COVID-19 ditularkan dari orang yang bergejala (simptomatik) ke orang lain yang berada jarak dekat melalui droplet. Penularan juga dapat terjadi melalui benda dan permukaan yang terkontaminasi droplet di sekitar orang yang terinfeksi. Penularan virus COVID-19 dapat terjadi melalui kontak langsung dengan orang yang terinfeksi dan kontak tidak langsung dengan permukaan atau benda yang digunakan pada orang yang terinfeksi, Penularan droplet terjadi ketika seseorang berada pada jarak dekat (dalam 1 meter) dengan seseorang yang memiliki gejala pernapasan (misalnya, batuk atau bersin) sehingga droplet berisiko mengenai mukosa (mulut dan hidung) atau konjungtiva (mata). Penularan juga dapat terjadi melalui benda dan permukaan yang terkontaminasi droplet di sekitar orang yang terinfeksi [1].

Pandemi SARS COV-2 penyebarannya yang sopradis dan massif pada awal tahun 2020 hingga pertengahan tahun 2020, informasi bahwa kasus kematian terjadi 65 negara dengan rata-rata jumlah kematian $0.8 \%-10.8 \%$ [2], pada saat 30 hari pertama nilai transmisi penularan diperkirakan (mean $\pm \mathrm{SE}$ ) selama enam hari (mean $\pm \mathrm{SE}) \mathrm{RO}=2.58 \pm 2.53$ dan pada saat bulan April RO berkurang sampai dengan $65 \%$ atau $\mathrm{RO}=1.12 \pm 0.02$ sedangkan di Cina angka repuduksi (Rt) menurun sampai dengan bulan April yaitu $\mathrm{Rt}=0.914$ \pm 0.10 [3]. Di seluruh dunia mengalami perubahan dalam prinsip tatanan pola hidup yang berkaitan dengan penyebaran virus ini ditengah-tengah masyarakat dunia. Kurva insiden yang terus meningkat sehingga organisasi kesehatan dunia (WHO) telah mengeluarkan protokol atau aturan baku Social distancing dan Physical distancing bahwa menurut aturan tersebut untuk kepentingan kehidupan baru pada masyarakat dengan harapan bahwa pola kehidupan masyarakat pada umumnya dapat terhindar dari penyakit mematikan COVID-19.

Pemerintah Republik Indonesia melalui Keputusan Presiden Nomor 11 tahun 2020 tentang Penerapan Kedaruratan Kesehatan Masyarakat untuk menyikapi pandemi COVID-19 telah berupaya secara maksimal melakukan upaya kuratif, preventif dan promotif yang disampaikan oleh BNPB (Badan Nasional Penanggulangan Bencana) dan lembaga teknis Kementerian Kesehatan Republik Indonesia yang bermitra dan bersinergi dengan semua pemerhati dalam menekan penyebaran infeksi COVID-19 secara sporadis di Indonesia, mengingat bahwa pada awal tiga bulan pertama masa pandemi banyak mengalami kendala karena wilayah negara Indonesia adalah sebagain besar terdiri dari kepulauan, situasi ini menyebabkan sehingga Pemerintah Daerah melakukan tindakan yang diharapkan dapat menekan laju penyebaran angka infeksi seperti mengeluarkan himbauan dalam bentuk aturan PSBB (Pembatasan Sosial Berskala Besar), PSDD (Pembatasan Sosial Diperketat Diperluas) menutup kegiatan belajar mengajar di sekolah, perguruan tinggi menghentikan aktivitas pembelajaran manual digantikan dengan pembelajaran virtual, menutup pasar, menutup pusat perbelanjaan modern serta menutup jalur transportasi darat, laut dan udara lokal dalam daerah maupun regional antar daerah untuk membatasi mobilitas orang dari satu tempat ke tempat lainnya dan dengan waktu tertentu.

Kajian yang dilakukan oleh peneliti dari Badan Perencanaan Nasional (BAPPENAS) menggambarkan bahwa pemerintah dan lembaga kajian strategis memprediksi Indonesia tumbuh rendah atau bahkan negatif di tahun 2020. Untuk itu, Pemerintah berupaya mengagendakan kebijakan Normal Baru agar dampak ekonomi akibat pandemi tidak sampai menimbulkan krisis yang berkepanjangan. Kebijakan ini berhubungan dengan perencanaan pembangunan dimana Pemerintah sudah menetapkan program, target, dan major projects di Rencana Pembangunan Jangka Menengah Nasional (RPJMN) 2020-2024. Pemerintah perlu melakukan penelaahan kembali terhadap rencana jangka menengah mengingat pada tahun 2020 semua program dilakukan pengalihan fokus untuk penanganan COVID-19. Pemerintah mempunyai 3 alternatif dalam perencanaan jangka menengah, apakah tetap dengan rencana semula, melakukan revisi moderat, atau mengganti dengan rencana yang baru dengan mendasarkan asumsi yang sudah diperbaharui dengan datangnya pandemi COVID19 dan dampak ekonomi yang mengiringinya [4].

Masyarakat kurang kesadaran serta ketaatan saat masa pandemi adalah salah satu pemicu peningkatan penyebaran COVID-19 [5], perlu tetap mempertahankan pengawasan ketat terutama ketika mulai beralih dari PSBB menjadi kebijakan dalam kondisi normal baru [6], kebijakan lock down pertama kali dilakukan oleh beberapa daerah di Indonesia misalnya Provinsi Papua telah menutup akses keluar-masuk dari pintu laut (pelabuhan), udara (bandara), maupun darat (PLBN), Kota Tegal melaksanakan mekanisme isolasi wilayah atau karantina wilayah hal ini dilaksanakan untuk melindungi warga Tegal dari penyebaran penularan COVID-19 dan Tasikmalaya, penerapan karantina wilayah dengan mekanisme meminimalkan masyarakat yang akan mudik ke kampung halaman [7], Kesadaran dalam menaati protokol kesehatan merupakan salah satu 
cara yang dikeluarkan oleh pemerintah dengan harapan bahwa semakin dipercayai oleh masyarakat tentang aturan yang diberlakukan dari pemerintah maka masyarakat akan terhindar oleh pandemi COVID-19 [8],[9]. Perilaku terjadi melalui proses adanya stimulus terhadap organisme, dan kemudian organisme tersebut merespon, maka teori Skinner ini disebut teori 'S-O-R" (Stimulus-Organisme-Respons). Berdasarkan batasan dari Skinner tersebut, maka dapat didefinisikan bahwa perilaku adalah kegiatan atau aktivitas yang dilakukan oleh seseorang dalam rangka pemenuhan keinginan, kehendak, kebutuhan, nafsu, dan sebagainya [10].

Pemerintah Daerah Provinsi Papua berusaha semaksimal mungkin untuk melindungi masyarakat dengan mengeluarkan Surat Edaran No 550/2559/SET tentang Petunjuk Teknis dan Protokol Transportasi New Normal Kebiasan Baru Masyarakat Produktif dan Aman COVID-19 di Provinsi Papua kecuali di Kota Jayapura, aturan ini dikeluarkan dengan harapan bahwa masyarakat tetap taat terhadap protokol kesehatan. Kasus Covid-19 di Kota Jayapura terus bertambah dengan nilai Rt atau angka penambahan kasus sebesar $1.57 \%$ artinya bahwa wabah pandemi COVID-19 di Kota Jayapura belum terkontrol.

\section{Metode}

Penelitian kuantitatif dilakukan dengan observasional analitik menggunakan pendekatan crosssectional. Survei dilakukan selama 1 bulan yaitu pada bulan Agustus 2020. Area survei mencakup wilayah Kecamatan Jayapura Utara, Kecamatan Abepura dan Kecamatan Heram dan 10 Kelurahan serta 4 Kampung. Penjelasan kualitatif digali untuk mendukung temuan kuantitatif sehingga dapat menjelaskan variabel penyerta lainnya. Sampel survei berbasis probabilitas dengan menentukan sasaran dari populasi yaitu sebanyak 1033 responden. Analisis univariat dilakukan untuk mendeskripsikan masing-masing komponen variabel yang masuk dalam penelitian ini sedangkan Chi-square digunakan untuk menggambarkan probabilitas responden berisiko terinfeksi COVID-19 dan kemaknaan dari variabel penyerta.

\section{Hasil}

Jumlah partisipasi dari responden dalam penelitian untuk jenis kelamin laki-laki 534 orang $(51.7 \%)$ dan perempuan 499 orang (48.3\%). Hasil penelitian bahwa dari 1033 responden yang pernah mengikuti Rapid Diagnosis Test (RDT) ada 179 (17.3\%) sedangkan $854(82.7 \%)$ responden tidak partisipasi dalam perlakuan RDT. Hasil tes RDT menunjukkan 152 (14.2\%) responden negatif dan 881 (85.3\%) tidak menjawab dan memberikan informasi tentang hasil
RDT. Responden yang partisipasi mengikuti tes PCR (Polymerase Chain Reaction) ada $22(2.1 \%)$ responden sedangkan yang tidak berpartisipasi ada 1011 (97.9\%) responden. Sebaran responden terlihat pada arsiran dari peta wilayah adminitratif Kota Jayapura Survei Kepatuhan Protokol COVID-19 (Gambar 1)

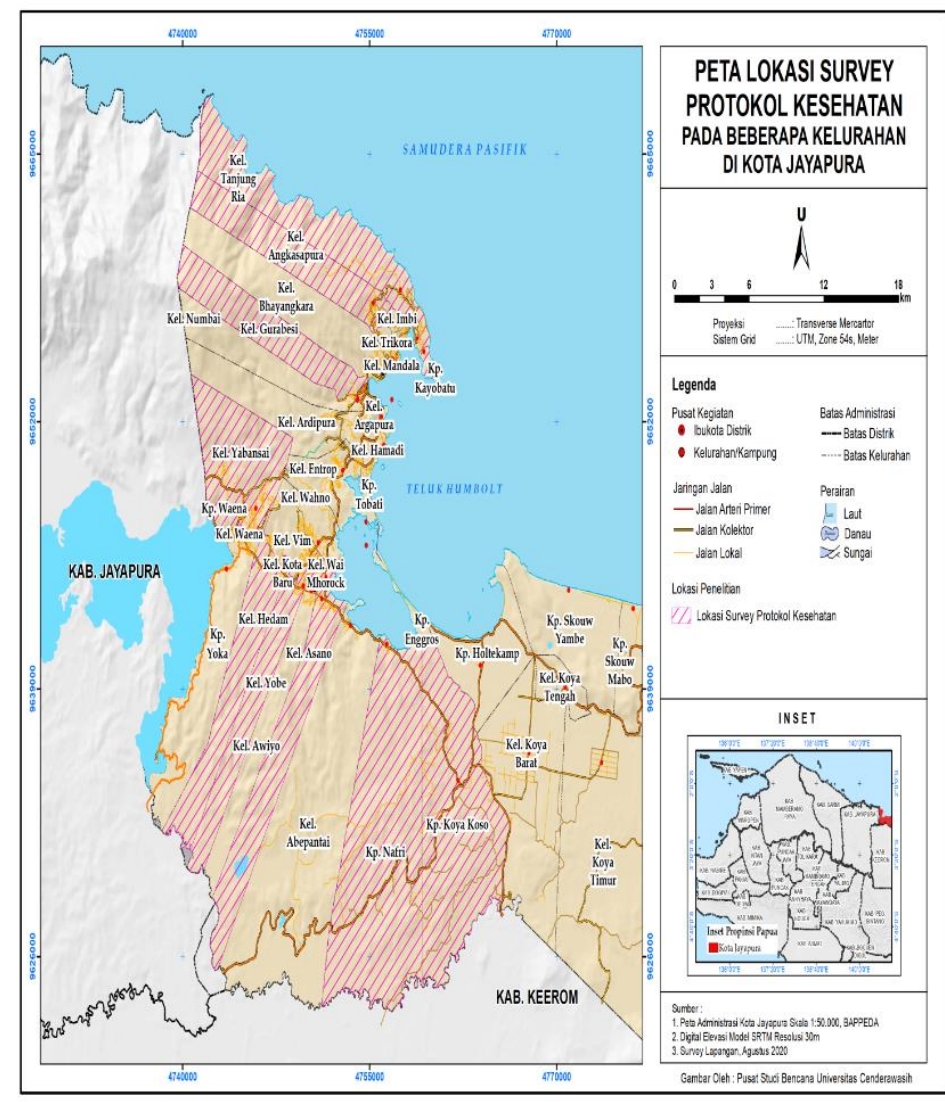

Gambar 1. Peta lokasi penyebaran responden survei protokol kesehatan di Kota Jayapura

Tabel 1. Karakteristik responden

\begin{tabular}{llcc}
\hline Variabel & & $\mathrm{f}$ & $(\%)$ \\
\hline \multicolumn{1}{l}{ Jenis kelamin } & & \\
& Laki-laki & 534 & 51.7 \\
Umur & Perempuan & 499 & 48.3 \\
& & & \\
& Dewasa & 847 & 82.0 \\
Pendidikan & Dewasa Lanjut & 186 & 18.0 \\
& Pendidikan Rendah & 186 & 18.0 \\
& Pendidikan Tinggi & 847 & 82.0 \\
Pekerjaan & & & \\
& Bekerja & 905 & 87.6 \\
\multirow{4}{*}{ Suku } & Tidak Bekerja & 128 & 12.4 \\
& & & \\
& Papua & 459 & 44.4 \\
Agama & Non-Papua & 574 & 56.6 \\
& & & \\
& Kristen & 638 & 61.8 \\
& Non-Kristen & 395 & 38.2 \\
\hline
\end{tabular}


Tabel 1 menunjukkan bahwa reponden lakilaki 534 orang $(51.7 \%)$ lebih banyak dibandingkan perempuan 499 orang (48.3\%), umur dewasa lebih banyak $(82.0 \%)$ dibandingan dengan umur dewasa lanjut $(18.0 \%)$, pendidikan untuk pendidikan rendah lebih sedikit (18.05\%) dibandingkan dengan pendidikan tinggi $(82.0 \%)$, responden yang bekerja lebih banyak $(87.6 \%)$ dibandingkan dengan yang tidak bekerja (12.4\%), suku Papua lebih sedikit (44.4\%) dibandingkan dengan suku non-Papua (56.6\%), dan responden beragama Kristen lebih banyak (61.8\%) dibandingkan dengan agama non-Kristen (38.2\%)

Tabel 2 menunjukkan bahwa seluruh variabel Karakteristik responden tidak berhubungan signifikan dengan pengetahuan tentang masker. Sebaliknya, hampir semua Karakteristik responden, kecuali jenis kelamin berhubungan dengan sikap terhadap penggunaan masker. Praktik penggunaan masker hanya dipengaruhi oleh suku.

Tabel 2. Karakteristik responden dan penggunaan masker

\begin{tabular}{lccccccccc}
\hline \multirow{2}{*}{ Variabel } & \multicolumn{3}{c}{ Pengetahuan Masker } & \multicolumn{3}{c}{ Sikap Masker } & \multicolumn{3}{c}{ Tindakan Masker } \\
\cline { 2 - 10 } & OR & CI 95\% & p & OR & CI 95\% & p & OR & CI 95\% & p \\
\hline Jenis Kelamin & 1.31 & $0.75-2.28$ & 0.41 & 1.05 & $0.82-1.35$ & 0.72 & 2.35 & $0.88-6.24$ & 0.12 \\
Umur & 1.37 & $0.53-3.52$ & 0.64 & 0.54 & $0.35-0.82$ & $0.00 *$ & 2.13 & $0.80-5.70$ & 0.21 \\
Pendidikan & 0.53 & $0.29-0.99$ & 0.06 & 1.09 & $0.78-1.52$ & 0.64 & 2.13 & $0.80-5.70$ & 0.21 \\
Pekerjaan & 1.37 & $0.53-3.52$ & 0.64 & 0.54 & $0.35-0.82$ & $0.00^{*}$ & 2.57 & $0.34-19.47$ & 0.54 \\
Suku & 1.03 & $0.59-1.80$ & 1.00 & 1.28 & $0.99-1.65$ & $0.00^{*}$ & 6.97 & $1.60-30.34$ & $0.00^{*}$ \\
Agama & 1.33 & $0.73-2.40$ & 0.42 & 1.40 & $1.08-1.82$ & $0.01 *$ & 2.56 & $0.89-5.65$ & 0.12 \\
\hline
\end{tabular}

* berhubungan signifikan

Respon masyarakat terhadap penerapan protokol kesehatan pada masa normal baru ditampilkan dalam dua kelompok: pro dan kontra. Data dari beberapa informan ditampilkan sebagai berikut:

\section{Respon dari masyarakat yang kontra dengan Protokol Kesehatan}

"Bapak-bapak Polisi selalu kasih pengumuman untuk kita masyarakat jaga jarak dan pakai masker, tapi bapak polisi tidak jalankan jaga jarak karena setelah berikan pengumumun semua naik dalam satu mobil bisa 5 orang tanpa mereka jaga jarak didalam mobil", (Informan menyampaikan bahwa aparat keamanan yang bertugas memberikan informasi tentang jaga jarak dan penggunaan masker namun saat bertugas tidak menerapkan konten informasi yang disampaikannya).

"Kita tidak mau di wawancarai nanti orang yang mau berbelanja tidak jadi berbelanja karena dikira kita ikut tes covid ....

(informan tidak bersedia untuk di wawancarai karena takut aktivitas perdagangannya terganggu dan konsumen menjauh)

"Sebenanya Covid itu ada ka tidak? Pemerintah selalu bilang jaga jarak pake masker karena covid ini angka semakin tinggi di Jayapura. Kita tidak tau orang-orang siapa yang kena Covid tapi angka itu selalu tinggi. Covid itu tidak ada cuman permaianan politik saja...." (informan menyampaikan bahwa keberadaan COVID19 ada atau tidak? Pemerintah menyampaikan untuk jaga jarak dan menggunakan masker, namun angka COVID-19 di Kota Jayapura selalu bertambah dan COVID-19 hanya kepentingan politik)

"Kita tidak percaya Corona itu ada pemerintah suruh kita jaga kebersihan jaga jarak supaya tidak kena corona tapi kita saja hari-hari dari dulu kerja di kebun kita kotor-kotor kita kumpul-kumpul dengan keluarga tapi kita tidak kena covid orang-orang sekitar kita tidak ada yang mati karena covid, jadi covid itu tidak ada kalau sakit malaria baru mati itu ada tapi covid tidak ada...."

(informan menyampaikan bahwa tidak mempercayai adanya COVID-19 walaupun pemerintah selalu menganjurkan untuk menjaga kebersihan dan jaga jarak agar terhindar dari COVID-19, namun kebiasaan informan yang bekerja di kebun dan berkumpul dengan keluarga dan orang di sekitar tidak terkena COVID-19. Apabila sakit malaria akan meninggal sedangkan COVID-19 tidak ada)

"Anak dorang bisa tanya di rumah sebelah dulu bapak/ibu kita tidak mengerti kita tidak tamat sekolah. Bisa tanya lain kah bapak/ibu tidak bisa membaca...... (informan menyampaikan bahwa tidak sekolah, tidak dapat membaca dan tidak mengerti)

“......Mama kitong biasa kalau ke kota boleh pake masker jaga jarak dengan orang, karena kitong tidak kenal orang-orang di kota. Tapi kalau kita di kampung sini kita jarang pake masker bahkan tidak pakai masker 
kita juga kalau duduk kumpul-kumpul dengan keluarga itu tidak jaga jarak karena kitong tau itu kita keluarga kita tau dia sehat atau tidak......"

(informan menyampaikan bahwa pada saat ke kota akan menjaga jarak dan menggunakan masker namun jika berada di lingkungan keluarga dan komunitasnya informan tidak menjaga jarak dan tidak menggunakan masker)

“......kita di dalam rumah saja kita ikuti protokol kesehatan tapi kapan covid ini berakhir pemerintah berikan anjuran ikuti protokol kesehatan tapi orang yang covid kita tidak tau dimana saja dan kita punya wilayah tempat tinggal juga masih di zona hijau....."

(Informan menyampaikan bahwa keberadaannya di rumah sudah menerapkan protokol kesehatan yang dianjurkan pemerintah tetapi tidak mengetahui kapan COVID-19 akan berakhir dan wilayah tempat tinggalnya masih di zona hijau)

“.....kita tidak tutup sesuai arahan yang diberikan karena masih ada pembeli yang membeli biasa itu mau tutup tapi kalau sebelah-sebelah belum tutup yah kita juga tidak tutup sampai pernah diusir tim keamanan baru kita tutup, kalau kita tinggal-tinggal saja begitu mau dapat uang dari mana kita tidak bisa makan jadi mau tidak mau kita buka saja sampai disuruh tutup baru kita tutup ........."

(informan menyampaikan bahwa tidak menutup kios sesuai anjuran pemerintah karena masih ada pelanggan yang ingin berbelanja namun jika ada pedagang lain yang belum menutup kiosnya maka informan juga menutup kios, karena apabila informan tidak membuka kios maka ia tidak mendapat penghasilan untuk makan) “....Covid itu sebenarnya penyakit yang bagaimana nanti kita pilek dibilang Covid, kita panas dibilang covid sampai kita menstruasi juga dibilang Covid....."

\section{Pembahasan}

Penerapan kebijakan dan peraturan oleh pemerintah kepada masyarakat dimaksudkan untuk kepatuhan tindakan pengunaan masker pada masa pandemi Covid-19 sehingga dapat menekan angka penularan [11]. Hal ini telah dilaporkan bahwa tindakan penggunaan masker pada masyarakat sangat berkontribusi dalam pengendalian COVID-19 karena masker dapat mengurangi percikan liur yang dihasilkan lewat percakapan atau kontak langsung dengan seseorang yang telah menunjukkan gejala sub klinis COVID-19 [12]. Angka penyebaran COVID-19 di Kota Jayapura setiap minggu bertambah salah satu penyebab utama adalah kurang patuhnya masyarakat saat melakukan aktivitas yang berkaitan dengan kehidupannya di kota ini. (informan bertanya tentang penyakit COVID-19 karena ketika pilek, demam dan menstruasi di diagnosis COVID-19)

“......Sekarang kalau kita sakit itu takut untuk berobat ke dokter nanti cuman malaria kita dibilang covid. Jadi sekarang semua petugas sibuk dengan covid baru penyakit lain tidak diurus karena semua yang sakit disebut sakit Covid...."

(informan menyampaikan bahwa ketika berobat ke dokter dan beranggapan sakit malaria namun di katakan COVID-19. Sekarang semua petugas kesehatan sibuk dengan COVID-19 dan mengabaikan penyakit lain karena semua penyakit diduga COVID-19)

\section{Respon dari kelompok yang Pro dengan Protokol Kesehatan:}

“.... tingkat penerimaaan di kelurahan ini baik, masyarakat mau saja untuk di wawancara tanpa harus ada tanda terima kasih....."

(informan menyampaikan bahwa tingkat penerimaan di beberapa kelurahan sudah baik karena masyarakat bersedia di wawancara secara sukarela tanpa adanya imbalan)

“..... ade-ade dorang datang survei begini bagus sekali jadi kita yang tidak tau cara cuci tangan yang benar jadi tau, dan kita juga dapat informasi tambahan tentang info PSDD di kota Jayapura..."

(informan menyampaikan bahwa kedatangan tim survei sangat baik karena dapat memberikan informasi tentang mencuci tangan yang benar dan mendapatkan informasi tambahan tentang PSDD (Pembatasan Sosial Diperketat Diperluas) di Kota Jayapura).

Hasil dalm penelitian ini menujukan bahwa karakteristik responden suku memiliki tindakan berisiko dan probabilitas terinfeksi COVID-19. Kajian penelitian lain membahas bahwa penggunaan masker untuk mencegah penyebaran COVID-19 oleh beberapa negara membuktikan bahwa penggunaan masker oleh seseorang di dalam masyarakat sangat efektif mencegah penularan penyakit COVID-19. Informasi klinis tentang virulensi COVID-19 diikuti dengan kampanye penggunaan masker secara baik agar masyarakat dapat memahami tentang manfaat masker untuk mencegah pandemi virus COVID19 [13].

Hampir semua karakteristik responden berhubungan signifikan dengan penggunaan masker, 
kecuali jenis kelamin. Artinya sikap masyarakat Kota Jayapura terhadap penggunaan masker saat masa pandemi COVID-19 tidak ditentukan oleh jenis kelamin. Penduduk laki-laki maupun perempuan tidak memiliki sikap yang berbeda dalam mengindahkan protokol COVID-19 disaat pemberlakuan kehidupan normal baru. Semua karakteritik responden tidak berkaitan dengan pengetahuan tentang masker. Artinya bahwa pengetahuan masyarakat Kota Jayapura tentang arti penting masker dipengaruhi faktor lain, seperti penegakan peraturan, contoh dan keteladanan dari pemuka masyarakat dan aparatur pemerintah. Hal ini dapat ditunjukkan dari data kualitatif bahwa mereka menyayangkan aparatur pemerintah yang tidak konsisten dengan substansi yang dikomunikasikan. Sikap terhadap efektivitas penggunaan masker berguna untuk menekan penyakit menular, baik di lingkungan rumah sakit ataupun di tengah-tengah masyarakat. Dalam hal ini, pemerintah harus berupaya semaksimal mungkin untuk memberikan pemahaman tentang manfaat penggunaan masker, dan memastikan bahwa pasokan masker di tempat layanan kesehatan dan di masyarakat umum selalu tercukupi [14]. Penggunaan masker merupakan salah satu bagian komprehensif dalam protokol pencegahan dan pengendalian COVID-19, masker digunakan oleh orang sehat untuk melindungi diri saat berpapasan dengan orang sehat maupun orang yang sakit, namun penggunaan masker saja belum cukup harus menjaga kebersihan diri dan selalu jaga jarak dan tidak bersentuhan secara langsung dengan orang lain [15].

Kebiasaan mencuci tangan pada masa pandemi COVID-19 di Kota Jayapura berdasarkan hasil penelitian menunjukkan bahwa seseorang setelah berada di rumah artinya bahwa setelah melakukan aktivitas diluar jarang mencuci tangan kecuali ke tempat fasilitas pelayanan publik, pernyataan lain bahwa mencuci tangan saat akan makan dan apabila tangan dalam keadaan kotor. Penelitian tentang "Frequent Hand Washing for COVID19 Prevention Can Cause Hand Dermatitis: Management Tips" menjelaskan bahwa sering mencuci tangan akan terjadi perubahan patofisiologis pada telapak tangan seperti kerusakan jaringan keritinosit dari proinflamasi dari jaringan kekebalan kulit tangan hal ini dapat terjadi pada orang dengan riwayat dermatitis atopik hal ini dapat dicegah dengan setelah mencuci tangan atau mengunakan hand sanitizer berulang kali maka harus mengunakan pelembab agar kulit tangan tidak kering dan terjadi iritasi [16]. Penelitian di wilayah pada pemukiman penduduk Nairobi Kenya menjelaskan bahwa salah satu metode pencegahan COVID-19 yaitu dengan mencuci tangan walaupun $37 \%$ orang menyampaikan tidak memiliki sumber air yang baik di lingkungan perumahannya dan $53 \%$ orang menyatakan bahwa penggunaan hand sanitizer menghambat virus COVID-19 walaupun harganya mahal [17]. Pembahasan dalam penelitian yang berjudul "COVID-19: urgent actions, critical reflections and future relevance of 'WaSH': lessons for the current and future pandemics" menjelaskan bahwa mencuci tangan berkaitan erat dengan ketersediaan dan terjangkauan pasokan air di masyarakat, perilaku kebersihan tangan pada beberapa negara berkembang sangat berpengaruh kepada akses ketersediaan penyediaan air bersih dan penggunaan sabun untuk mencuci tangan [18].

Kepatuhan terhadap protokol kesehatan yang tertib di negara Vietnam sehingga negara ini dapat menekan angka penyebaran infeksi COVID-19, kebiasaan orang Vietnam saat masa pandemi seperti menghindari pertemuan besar, pergi ke pasar, menghindari perjalanan dengan kendaraan/bus dengan lebih dari 10 orang, dan tidak bepergian ke luar wilayah selama masa lock down di Vietnam, ketaatan masyarakat dalam masa pandemi di negara Vietnam berbuah baik yaitu angka kesakitan COVID-19 di bawah standar internasional dan tidak ada kasus kematian COVID-19 [19]. Pemberlakuan situasi hidup normal baru di wilayah Kota Jayapura dengan harapan bahwa masyarakat selalu megikuti aturan protokol kesehatan dan batasan waktu aktivitas masyarakat dalam melakukan aktivitas soal di luar rumah, hasil penelitian mengambarkan bahwa masih tinggi masyarakat di Kota Jayapura yang tidak paham dengan aturan pembatasan hidup baru sedangkan proporsi angka kepatuhan new normal $80.1 \%$ untuk penerapan protokol kesehatan proporsinya $60.6 \%$ artinya masyarakat Kota Jayapura banyak yang tidak memahami new normal tapi masih patuhi protokol kesehatan dan patuh terhadap pemberlakuan aktivitas normal baru. Informasi kualitatif mengungkapkan bahwa ada informan yang masih mengabaikan tentang protokol kesehatan dengan alasan bahwa apabila mendapatkan pemberlakuan Komunikasi Edukasi dan Informasi COVID-19 maka informan tersebut diduga telah mendapatkan tes COVID-19 dan akan mendapatkan diskriminasi oleh orang lain yang berada di sekitar informan tersebut informan adalah keseharian sebagai pedangang pelaku ekonomi, informan lainnya mengungkapkan bahwa tidak mempercayai tentang pandemic COVID-19. Menggerakkan perputaran ekonomi serta patuh mengikuti aturan social distancing dan physical distancing berhasil menghambat laju perkembangan COVID-19 di tengah masyarakat [20]. 


\section{Kesimpulan}

Karateristik suku berkontribusi 7 kali terinfeksi COVID-19 di Kota Jayapura. Jenis kelamin, umur, pendidikan, pekerjaan dan agama berkontribusi 2 kali terhadap praktik penggunaan masker probabilitas $2 \mathrm{kali}$ terinfeksi COVID-19 di Kota Jayapura. Pemberlakuan protokol kesehatan COVID-19 di Kota Jayapura belum dipatuhi dengan baik oleh masyarakat.

\section{Daftar Pustaka}

[1] Kementerian Kesehatan Republik Indonesia. 2020. Pedoman Pencegahan dan Pengendalian COVID19 revisi ke-5. Diterbitkan oleh Kementerian Kesehatan RI

[2] Kenyon.C. 2020. Flattening-the-curve associated with reduced COVID-19 case fatality rates- an ecological analysis of 65 countries. Journal of Infection: journal homepage: www.elsevier.com/locate/jinf

[3] Chaves LF et al. 2020, COVID-19 Basic Reproduction Number and Assessment Of Initial Suppresion Policies In Costa Rica, Mathematics Subject Classification. 62P10, 92B05. Received April 7, 2020. Accepted May 7, 2020. Math. Model. Nat. Phenom. 15 (2020) 32 Mathematical Modelling of Natural Phenomena https://doi.org/10.1051/mmnp/2020019 www.mmnp-journal.org

[4] Muhyiddin, 2020, COVID-19, New Normal dan Perencanaan Pembangunan di Indonesia, Kementerian Perencanaan Pembangunan Nasional/Bappenas Republik Indonesia, https://journal.bappenas.go.id/index.php/jpp/articl e/view/118/89

[5] Arditama.E dan Lestari.P,2020, Jogo Tonggo, Membangkitkan Kesadaran dan Ketaan Warga Berbasis Kearifan Lokal Pada Masa Pandemi COVID-19 di Jawa Tengah, Jurnal Pendidikan Kewarganegaraan Undiksha Vol. 8 No. 2 (Mei, 2020) Open Access at : https://ejournal.undiksha.ac.id/index.php/JJPP

[6] Handayanto, R. T., \& Herlawati, H. (2020). Efektifitas Pembatasan Sosial Berskala Besar (PSBB) di Kota Bekasi Dalam Mengatasi COVID19 dengan Model Susceptible-Infected-Recovered (SIR). Jurnal Kajian Ilmiah, 20(2), 119-124. https://doi.org/10.31599/jki.v20i2.119

[7] Luhukay.R.S dan Hartanto,2020, Urugensi Penerapan Local Lock Down Guna Pencegahan Penyebaran COVID-19 Ditinjau Dari Prekspektif Negara Kesatuan, Adil Inonesia Jurnal Volume 2 Nomor 2, Juli 2020,
http://jurnal.unw.ac.id:1254/index.php/AIJ/article/ view/624/454

[8] Mahardika.M.N, et al, 2020), Stategi Pemerintah Dan Kepatuhan Masyarakat Dalam Mengatasi Wabah COVID 19 Berbasis Semangat Gtong Royong, Jurnal Ilmiah Kajian Pendidikan, http://ejurnal.unisri.ac.id/index.php/glbctz/article/ view/... Diterima : 06-03-2020, Disetujui : 11-052020 Dipublikasikan: 1-07-2020, http://ejurnal.unisri.ac.id/index.php/glbctz/article/ view/3884/3171

[9] Azrul, A.1999. Pengantar Epidemiologi, Jakarta, Binarupa Aksara

[10] Soekidjo N, 2007, Promosi Kesehatan dan Ilmu Perilaku, Rineka Cipta, Jakarta 2007

[11] Wei Lyu and George L. Wehby, 2020, Community Use Of Face Masks And COVID-19: Evidence From A Natural Experiment Of State Mandates In The US, Downloaded from Health Affairs.org on September 17, 2020. All rights reserved. Reuse permissions at Health Affairs.org. August 2020, doi: $\quad 10.1377 /$ hlthaff.2020.00818 HEALTH AFFAIRS 39, NO. 8 (2020): 1419-1425 (C2020 Project HOPE — The People-to-People Health Foundation, Inc.

[12] Vincent Chi.C.C, Shuk.C.Wong, et al, 2020, The role of community-wide wearing of face mask for control of coronavirus disease 2019 (COVID-19) epidemic due to SARS-CoV-2, Contents lists available at ScienceDirect Journal of Infection journal homepage: www.elsevier.com/locate/jinf

[13] Ricky V.T, and Benjamin J.C, 2020, Importance of Face Masks for COVID-19: A Call for Effective Public Education, Clinical Infectious Diseases, 1 Department of Psychology \& Psychological Assessment and Clinical Research Unit, Education University of Hong Kong, Hong Kong Special Administrative Region (SAR), China, and 2 School of Public Health, Li Ka Shing Faculty of Medicine, University of Hong Kong, Hong Kong SAR, China.

[14] Jiao Wang, et al, 2020, Mask use during COVID19: A risk adjusted strategy, Contents lists available at Science Direct Environmental Pollution journal homepage: www.elsevier.com/locate/envpol Article history: Received 6 May 2020 Received in revised form 23 June 2020 Accepted 23 June 2020 Available online 25 June 2020

[15] WHO, 2020, Advice on the use of masks in the context of COVID-19, Interim guidance, 5 June 2020 , 
https://apps.who.int/iris/bitstream/handle/10665/3 32293/WHO-2019-nCov-IPC_Masks-2020.4eng.pdf

[16] Cristina Beiu, et al, (2020), Frequent Hand Washing for COVID-19 Prevention Can Cause Hand Dermatitis: Management Tips, How to cite this article Beiu C, Mihai M, Popa L, et al. (April 02, 2020) : Management Tips. Cureus 12(4): e7506.

DOI

10.7759/cureus.7506,file:///D:/Survei\%20Covid1 9\%20Kota\%20Jayapura/Frequent $\% 20 \mathrm{Hand} \% 20$ Washing\%20for\%20COVID19.pdf

[17] Karen Austrian, et al, 2020, COVID-19 related knowledge, attitudes, practices and needs of households in informal settlements in Nairobi, Kenya, file:///C:/Users/admin/Downloads/SSRNid3576785.pdf

[18] Guy Howard, et al, 2020, COVID-19: urgent actions, critical reflections and future relevance of 'WaSH': lessons for the current and future pandemics, Journal of Water, Sanitation and Hygiene for Development in press 2020, This is an Open Access article distributed under the terms of the Creative Commons Attribution Licence (CC BY 4.0), which permits copying, adaptation and redistribution, provided the original work is properly cited http://creativecommons.org/licenses/by/4.0/ • 1 Review Paper (C) 2020 doi: 10.2166/washdev.2020.218

[19] Nhan Phuc Thanh Nguyen,et al, 2020, Preventive behavior of Vietnamese people in response to the COVID-19 pandemic, Citation: Nguyen NPT, Hoang TD, Tran VT, Vu CT, Siewe Fodjo JN, Colebunders R, et al. (2020) Preventive behavior of Vietnamese people in response to the COVID19 pandemic. PLoS ONE 15(9): e0238830. https://doi.org/10.1371/journal. pone.0238830 Editor: James C

[20] Wright.A.L, 2020, Poverty and Economic Dislocation Reduce Compliance with COVID-19 Shelter-in-Place Protokols, 5757 S. University Ave. Chicago, IL 60637 Main: 773.702.5599 bfi.uchicago.edu.

file://C:/Users/admin/Downloads/SSRNid3573637.pdf 